\title{
The "Aku Bisa" Program; Efforts to Train Early Childhood Independence
}

\author{
Fathor Rozi ${ }^{\otimes}{ }^{\otimes}$, Faizatul Widat ${ }^{2}$, Latifatus Saleha ${ }^{3}$, Arofatus Zainiyah ${ }^{3}$, Siti Nur Aisyah ${ }^{3}$ \\ Pendidikan Agama Islam, Universitas Nurul Jadid, Paiton, Probolinggo, Indonesia(1) \\ Pendidikan Guru Madrasah Ibtidaiyah, Universitas Nurul Jadid, Paiton, Probolinggo, \\ Indonesia(2); Pendidikan Anak Usia Dini, Universitas Nurul Jadid, Paiton, Probolinggo, \\ Indonesia(3) \\ DOI: $10.31004 /$ obsesi.v6i4.2067
}

\begin{abstract}
Early childhood is a period that requires guidance and development of self-development in order to train independence. However, training independence in early childhood cannot be done carelessly and must start from small things. This study aims to examine efforts to train early childhood independence through the "I Can" program based on self-accustoming at Sinar Harapan Kindergarten, Kedopok, Probolinggo. This research uses a descriptive qualitative approach with a case study type to examine the program. After the data were collected through interviews and observations, the data analysis techniques were data reduction, data display, and data verification. The results showed that the "Aku Bisa" program consisted of routine activities carried out from the time students arrived at school until the time of learning was over and evaluation with the parents of students every two months. The implication is that efforts to train children's independence will be successful if parents also support program activities and monitor their development.
\end{abstract}

Keywords: early childhood; independence; "aku bisa" program

\begin{abstract}
Abstrak
Masa anak usia dini tergolong dalam periode yang membutuhkan bimbingan dan pembinaan pengembangan diri guna melatih kemandirian. Namun, melatih kemandirian pada anak usia dini tidak dapat dilakukan sembarangan dan harus dimulai dari hal kecil. Penelitian ini bertujuan untuk mengkaji upaya melatih kemandirian anak usia dini melalui program "Aku Bisa" yang berbasis pembiasaan diri di TK Sinar Harapan, Kedopok, Probolinggo. Untuk mengkaji program tersebut, penelitian ini menggunakan pendekatan kualitatif deskriptif dengan jenis studi kasus. Adapun teknik analisis data yang digunakan setelah data terkumpul melalui wawancara dan observasi yakni reduksi data, display data, dan verifikasi data. Hasil penelitian menunjukkan bahwa program "Aku Bisa" terdiri atas kegiatan-kegiatan rutin yang dilakukan sejak anak didik tiba di sekolah hingga waktu pembelajaran usai serta evaluasi bersama wali murid setiap dua bulan sekali. Implikasinya, upaya melatih kemandirian anak akan berhasil apabila orang tua juga turut mendukung kegiatan program dan memantau perkembangannya.
\end{abstract}

Kata Kunci: anak usia dini; kemandirian; program "Aku Bisa"

Copyright (c) 2022 Fathor Rozi, et al.

$\triangle$ Corresponding author :

Email Address : fathorrozi330@gmail.com (Paiton, Probolinggo, JawaTimur, Indonesia)

Received 14 November 2021, Accepted 26 December 2021, Published 23 February 2022 


\section{INTRODUCTION}

During early childhood development, moral education is needed to provide children's ability to adapt to any environment. Moral education seeks to instill good manners, norms, and ethics in everyday life (Maryam, 2018; Mufarochah, 2020; Muali et al., 2021). Moral education also needs to be held because there is a weakening of family ties (Mahmudah, 2018), the emergence of negative tendencies in the lives of adolescents in the era of globalization, and the need for ethical, moral, and character values (Baharun, 2017; Kusumawati \& Zuchdi, 2019). Related to this, independence is one of the essential moral education to be instilled in children from an early age (Zulfaizah, 2018; Daviq, 2019). Investing freedom from an early age is needed to prepare children to become quality individuals and get along with other people when they are adults.

Practicing independence in early childhood can prevent children from being dependent on others (Iltiqoiyah, 2020). In learning independence, a child will learn to deal with various situations in his social environment to think and take appropriate action when faced with a problem (Sitanggang \& Nuriyanti, 2019; Ramdlani et al., 2021). More, Kartono (in Affrida, 2017) also argues that early childhood with an age range of 3-6 years has entered preschool age where children learn to join in the broader environment, namely the Playground or Kindergarten environment. Thus, it is clear that apart from parents (Finori, 2019), educational institutions at the Kindergarten level also have an essential role in training children's independence (Alfina \& Anwar, 2020; Zamroni et al., 2021; Umiarso \& Hidayati, 2022).

UNESCO (United Nations of Educational, Scientific, and Cultural Organization) states that there are four pillars in the implementation of education: learning to know, learning to do, learning to be, and learning to live together. It is in the third pillar (learning to be) that education is expected to educate and train children to grow into independent individuals so that they can realize their dreams and aspirations (Indak \& Pratiwi, 2021; Amaliyah et al., 2022). In practicing independence, of course, it is necessary to remember that the tasks of early childhood development in terms of autonomy include learning to walk, eat, talk, body coordination, feeling contact with the social environment, forming an understanding of something, and teaching morals (Nuraeni, 2016; Lana, 2021). These developmental tasks are much different from the task of developing the independence of teenagers who must be able to take responsibility for what they do. Kindergarten teachers must understand this in training children's independence (Wahid et al., 2022).

Children's independence is limited to matters relating to physical and psychological conditions so that children learn to make their own decisions, be responsible, and be confident. In detail, early childhood independence indicators can be seen from physical ability, selfconfidence, responsibility, discipline, good at getting along, sharing, controlling emotions (Daviq, 2019). For this reason, a teacher who is responsible for learning activities has a vital role in training and familiarizing children to be independent in carrying out every move, both physically and psychologically (Ali \& Lukmanulhakim, 2019). In this case, the teacher is tasked with being a mentor and an example for children in the training and developing independence (Mundiri et al., 2022).

However, guiding and setting an example for children is not enough to train independence. As happened in Sinar Harapan Kindergarten, Probolinggo, at the beginning of entering the school environment, students often do not want to be left behind by their parents, have not been able to go to the restroom themselves, have not been able to put, arrange, and take shoes and bags in their place, have not been able to tidy up tools. Writing and toys have been used, and he does not want to hang out with his new friends. These problems indicate that the independence of students has not been fully formed. Of course, this incompetence troubles the teacher responsible for dozens of students in each class. Students' freedom at the kindergarten level cannot grow and develop independently but requires help and training from the adults around them (Garnika \& Suarti, 2018). When at school, teachers become adults who must train children's independence. 
The independence of children that occurs in Sinar Harapan Kindergarten must be overcome so that children do not always depend on others when they grow up. Therefore, the Sinar Harapan Kindergarten teacher council created a program to train children's independence. The program is named "Aku Bisa". As the name implies, this program aims to train independence so that children "can" do many things on their own without the need to depend on others. This program is an effort to train independence through habituation. The habituation in question is in the form of simple activities from when students come to school until it is time to go home. The habituation-based "Aku Bisa" program is appropriate because the formation of children's independence requires repeated and continuous encouragement and stimulation (Silranti, 2019). In addition, if a positive habit is programmed correctly, it will be embedded in the child's memory and integrated into a permanent life skill (Krobo, 2021).

To obtain a detailed and in-depth discussion, the researcher also reviewed several previous studies relevant to children's independence. For example, in the first study (Atalia et al., 2021) entitled "Teachers' Efforts in Training Early Childhood Independence," children's independence can be increased if the teacher prepares and makes interesting learning strategies in integrating freedom learning with children's learning activities. However, the spirit and awareness of teachers in training children's independence will be hampered if parents are overprotective or spoil their children too much. While in other studies (Rukmandari et al., 2020) entitled "Efforts to Train Independence in Children Based on Working Parents" found that children's independence can be trained with parental awareness in getting children used to doing their activities providing positive verbal support (Jennah, 2019). There is also research (Simatupang et al., 2021) entitled "Cultivation of Independence in Early Childhood in Schools" states that the inculcation of the value of children's independent character is done by telling the concept of the pillars of independent character accompanied by discussion (recalling) related to the story so that children better understand and understand what it means to be separated. Of course, this storytelling activity is also accompanied by direct self-reliance practices at school, such as lining up neatly in front of the class, taking off shoes, and arranging bags and caps in their places.

From several previous studies that the author reviewed, it can be seen that children's independence can be achieved if there is direct practice accompanied by adult support around the child. As for this study, the authors examine efforts to train children's independence through a kindergarten-level institution's program. With the establishment of a program, children's independence training becomes more structured and systematic to make it easier to achieve goals. This can happen because a program that combines physical activity with teacher teaching will significantly impact early childhood(Hecht \& Garber, 2021). In addition, a planned program shows that teachers have the discipline to implement the designed program (Sufiati \& Afifah, 2019). From the occupation carried out by the teacher, the child will get an example of building independence in himself because independence is also influenced by selfdiscipline (Suhandi A \& Lestari T, 2021).

In addition to the fundamental differences described above, this study also examines an educational institution where the majority of the guardians of the students are families of middle to upper economic class. In general, children from middle to upper economic class families are always spoiled by their parents. The parents will give what the child wants without considering the benefits. This makes children not independent because they cannot overcome problems, lack patience, and lack self-confidence. On the other hand, economically affluent parents tend to control all their children's activities so that children do not have the opportunity to make their own decisions. When children are not used to making their own decisions, they will grow up to be not independent. This is a challenge in implementing the "Aku Bisa" program; this research's uniqueness distinguishes it from other research.

Based on the exposure of the urgency of practicing independence through the "Aku Bisa" program, this research is important to do to find out what activities are covered in the program in overcoming the unindependence of early childhood. The goal is to study efforts to 
train early childhood independence through the "Aku Bisa" program based on selfhabituation. By reviewing the "Aku Bisa" program applied in Sinar Harapan Kindergarten, it can be known what things teachers need to do in school so that children no longer depend on others and are more confident when hanging out in their social environment. Because, when a teacher seeks to develop the child's independence component through planned habituation, then the child will learn to manage emotions and self-will to be independent.

Early childhood is the child whose in the age range of 0-6 years. At this age, development occurs very rapidly. Based on the results of the study, about $40 \%$ of human development occurs at an early age (Khaironi, 2018). That's why early childhood is called the golden age. This period are valuable years for a child to recognize various facts in his environment as stimulants to the development of personality, psychomotor, cognitive and social (Tanu, 2019). The golden age period is characterized by the emergence of a period of exploration, a period of identification / imitation, a period of sensitivity, playing time, and a period of defiant (Sriwahyuni et al., 2017).

The child has special characteristics and not the same as adult. They are active, dynamic, enthusiasm and curiosity about what they seen, heard, and felt, as if they never stop to explore and learn. The child is egocentric and have natural curiosity (Ariyanti, 2016). So, child is a social creature, unique, rich with fantasy. It means, early childhood is a time as the most potential to learn. For this reason, children's education in the form of stimulation by parents, teachers and the immediate environment is needed to optimize the child's abilities and development.

Related to early childhood education, it can affect the child's brain development, health, readiness for school, better social and economic life in the future. Early childhood education provides efforts to stimulate, guide, honing, and providing activities that will produce the ability, as well as child skills (U. Hasanah, 2018). According to Montessori, the child's education must be in accordance with the stages child development (Elytasari, 2017). That way, the children progress through a series of stages of development. But every stage requires a type of learning that is precisely and specifically designed. So, early childhood requires an intensive education in order to develop a variety of potential of children from an early age as preparation to live and to be able to adjust with the environment.

Independence is defined as a condition in which a person does not rely on others in making decisions and have a confident attitude (Nasution, 2017). Independence makes a child able to make the choice that he thinks is right, besides that he dares to decide is choice and be responsible for the risks and consequences resulting from his choice. To instilling the soul of independence in children, it takes a series of serious efforts. Self-reliance is related to an independent person, creative and able to stand alone that has the confidence that can make a person be able as an individual to adapt and take care of everything with himself.

Independence in early childhood is characterized by the ability of children to choose themselves, creative, initiative, regulate behavior, be responsible, able to refrain, make their own decisions, and be able to overcome problems without the influence of others (D. R. Sari \& Rasyidah, 2020). In general, independence can be measured through how the child acts physically practiced. However, self-reliance can also be in the emotional and social behavior (Sukatin et al., 2019). A simple example, a child aged 3-4 years who can use cutlery, should be able to eat on his/her own, this is form of physical independence. Children who can enter the classroom comfortably because they can control themself is also a form of emotional independence.

In children of age preschool, one of the potentials that must be developed is independence because of the child began to separate himself from his parents and the child will enter a wider environment. Related to this, teachers in the learning process in the classroom are seen to play an important role in encouraging children's independence (Anggraeni, 2017). Independence means a child whose creativity is good, that's why must be able to create a learning atmosphere that stimulates children to want to know learning 
materials, enjoy asking questions, and dare to make opinions and conduct experiments that demand new experiences (Nuranisa et al., 2018).

\section{METHODOLOGY}

In this study, the object of study is the independence of early childhood. Children's independence must be trained from an early age with the help of adults around them, one of which is the teacher at school. As an educator, the teacher must instill, train, and develop an attitude of independence which is included in the value of character education. For this reason, the "Aku Bisa" program became a topic of discussion in research to examine the efforts of teachers at Sinar Harapan Kindergarten in training the independence of their students, the majority of whom come from middle to upper economic class families.

So that the discussion of the object of study for the "Aku Bisa" program can be presented clearly and systematically, a research design is needed. Research design is required to explain what, why, and how a problem is researched and studied using the principles of scientific methodology (Gulo, 2002). Regarding the research design, this study used a descriptive qualitative approach. This approach was chosen so that researchers can give a complete picture of a phenomenon (Farida, 2014). In this case, the phenomenon in question is implementing the "Aku Bisa" program as an effort to train children's independence in Sinar Harapan Kindergarten. Meanwhile, the type of research used by the researcher is a case study because this study examines a specific subject, namely Sinar Harapan Kindergarten.

As a case study research, the data sources in this study were obtained by conducting interviews and in-depth observations. To support the validity of these observations, the researchers also documented the "Aku Bisa" program at Sinar Harapan Kindergarten, Jrebeng Wetan sub-district, Kedopok sub-district, Probolinggo city. The informants in this study were Syamsul Ariefin as the head of the kindergarten; Ririn Widiastutik; Vivin Umami; and Urfiani as a teacher at Sinar Harapan Kindergarten. The data analysis process in this study can be seen from the following figure 1 .

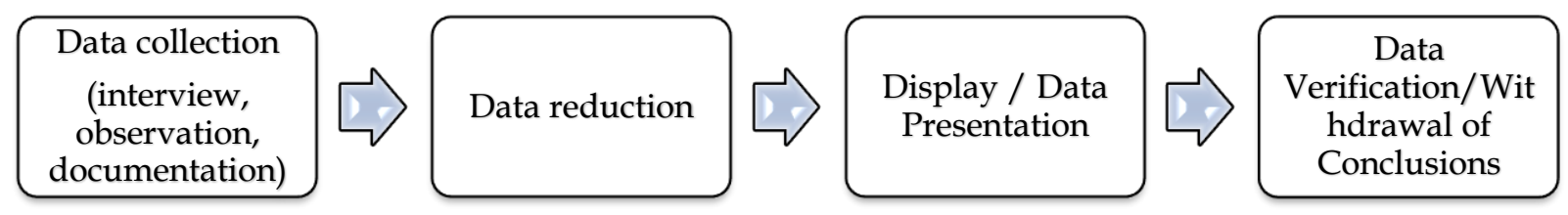

Figure 1 Stages of Data Analysis Techniques (Miles et al., 2013)

Figure 1 shows the process of the stages of data analysis techniques that begin with collecting data through interviews and observations accompanied by documentation. After all the data has been collected, the researcher reduces the data by sorting and selecting critical data according to the research topic. The reduced information is then presented in the research in a clear, coherent, and systematic way so that it is easy to understand. Finally, the research results that have been given are verified to obtain conclusions.

\section{RESULTS AND DISCUSSION}

Young children entering the school environment for the first time often have difficulty adapting. One of the causes of problems in adapting experienced by early childhood is a lack of independence. From observations made at Sinar Harapan Kindergarten, Probolinggo City, it was found that some attitudes were less independent in grade A students who were still in the early stages of entering the school world. 
DOI: 10.31004/obsesi.v6i4.2067

\section{The Form of Children Unindependence}

There are 29 students in class A of Sinar Harapan Kindergarten, with 14 children in class A1 and 15 children in class A2. Of the total 29 children, the children's attitude of lack of independence includes the following.

First, do not want to be left by their parents. The majority of class A students at Sinar Harapan Kindergarten do not want to leave their parents behind when they are at school. Children even often cry when they enter the classroom. Vivin Umami (2021), the homeroom teacher of class A2, revealed that 3 of his students still had to be accompanied by their parents in the classroom for the first two weeks of learning. While in class A1 there is also one child who still has to be accompanied by his parents until the learning ends at $10.00 \mathrm{WIB}$. However, some parents of other students waited outside the classroom.

Second, does not want to hang out with his friends. This is also one of the forms of nonindependence of students that most often occurs in Sinar Harapan Kindergarten. During recess, class A students usually approach their parents who are waiting outside the classroom or just buy food at the cooperative and then return to class.Even when learning takes place, students still look awkward with their friends next to them and don't talk much. In fact, in the first month of learning at school, one student in class A1 still didn't want to hang out with his friends at all. Urfiani(2021), as the homeroom teacher, A1, added that the child only wanted to talk to the teacher when asked. Hence, the teacher had to place him near the teacher's desk to make it easier to monitor the activities and conditions of the students.

Third, don't dare to go to the bathroom. That is, some students sometimes urinate or defecate in class. In class A1, two children often urinate or defecate in class. Meanwhile, in class A2, two children often defecate in class, but the other two children do the same, although not as often as the first two children. This condition is often inconvenient for a teacher who teaches, educates, and supervises more than five children in one class. The teacher for lessons A1 and A2 explained that usually, the teacher would take the child to the bathroom to help and protect the student from accidents such as slipping or falling in the bathroom. In addition, the teacher will also ensure that the condition of the toilet is clean again after use.

Fourth, unable to tidy up bags, shoes, and stationery after use. The age range of class A students at Sinar Harapan Kindergarten is 4-5 years old, so most can obey the teacher's orders when asked to tidy up their things. Indeed, during the first month or so of learning at school, the tidiness can't be said to be good.However, four students in class A could not tidy up the bags, shoes, and stationery they had used and just kept quiet or cried when the teacher asked them to tidy them up. Sometimes, the students' parents tidy up their bags and shoes at the beginning of the lesson. Then, at the end of the study, parents enter the classroom to tidy up their children's writing instruments.

Fifth, don't want to put your shoes on. After the lesson is over and all the students want to go home from school, they have to take their shoes from the shoe rack and put them on. However, two students in class A2 still don't want to put on their shoes and only sit at the front of the class when no one puts on their shoes. Therefore, the homeroom teacher of class A2 or another class teacher saw it. Sometimes, the child's parents have been waiting in front of the class before the lesson is over so that when the child leaves the course, the parents immediately pick up and put on the shoes. Of the several forms of independence of children in grades A1 and A2 Sinar Harapan Kindergarten, the following is a Venn diagram to map this information in more detail.

Figure 2 shows that from a total of 29 children in grades A1 and A2, the most not independent attitude occurred was not wanting to be left behind, namely nine students who their parents always accompanied, both inside and outside the classroom. Then, eight children did not want to hang out with their friends. One child still does not want to hang out with anyone for a month. The other six children did not dare go to the bathroom and often urinated or defecated in class. 4 children cannot tidy up their things and are still waiting for the teacher 
or their parents to help tidy up. At the same time, the remaining two people did not want to and could not put their shoes on.

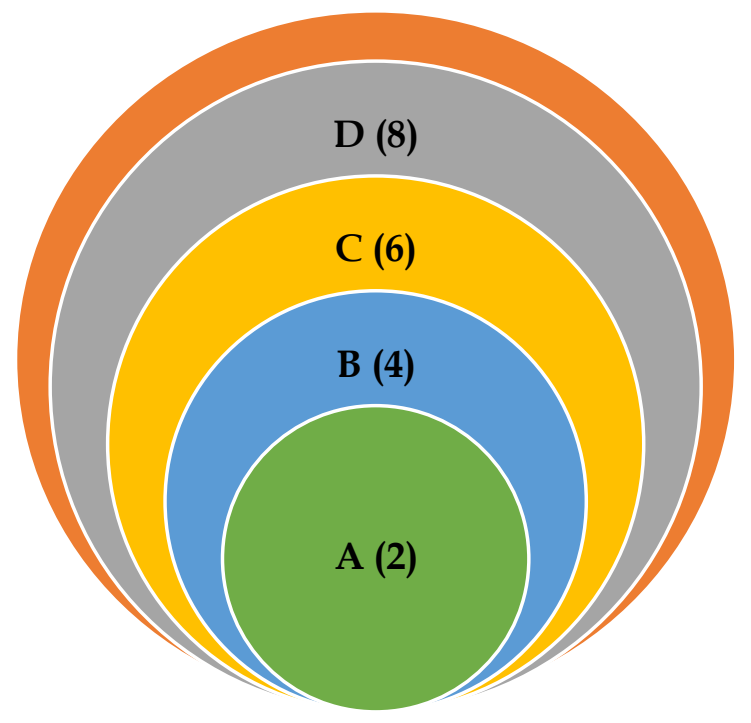

Information:

A. Don't want to put on your shoes

B. Can't tidy up bags, shoes, and stationery after use

C. Don't dare to go to the bathroom

D. Don't want to hang out with his friends

E. Don't want to be left by your parents

Figure 2 Venn Diagram of Unindependent Attitude of Class A Students (Urfiani, 2021a)

As a Venn diagram, member A includes member B, member B includes member C, member $\mathrm{C}$ includes member $\mathrm{D}$, and member $\mathrm{D}$ includes member $\mathrm{E}$. This means that all 29 students in class A, totaling 29 children, experienced independence in terms of not wanting to leave by parents.However, the number 9 in the diagram refers to the child who has the most difficulty being abandoned by his parents (the letter $\mathrm{E}$ in the diagram). At the same time, the remaining 20 people experienced significant independence in other respects indicated by the letters D, C, B, and A. The same is true for the other letter indicators. Numbers 8, 6, 4, and 2 only refer to children whose level of independence is high and often interferes with the effectiveness of the teaching and learning process.

There are still several other forms of independence to be found. For example, if a teacher does not accompany them, children do not want to unwrap their food and wash their hands after eating or after teaching activities. Some do not want to color or carry out other learning activities if the teacher or parents do not accompany them. If these attitudes are allowed, the child will remain dependent on others and cannot adapt well to his new environment.

Unfortunately, parents' attitude in dealing with their children who are still not independent makes them not independent. This is because parents wait for their children in front of the class or even enter the classroom. This eventually becomes an inhibiting factor for children in growing an independent attitude in themselves. In addition, the presence of parents in the school can interfere with the conduciveness of the learning process.

\section{The "Aku Bisa" Program at Sinar Harapan Kindergarten}

In training independence and overcoming various problems caused by the freedom of class A students, Sinar Harapan Kindergarten took the initiative to create an "Aku Bisa" program. The "Aku Bisa" program is a series of activities from when the children arrive at school until the learning time ends at 10.00 WIB. Sinar Harapan Kindergarten Principal (Ariefin, 2021)explained that the purpose of the "Aku Bisa" program was to train children to be independent by making routine but straightforward habits. The activities contained in the "Aku Bisa" program include the following. 
First, enter the school gate without being escorted by parents and shake hands with the teacher. In this activity, all Sinar Harapan Kindergarten teachers consisting of 4 people (homeroom A1, homeroom A2, homeroom B1, and homeroom B2) will stand in front of the school gate and wait for students to arrive at 07.30 WIB. The teachers' placement in front of the school gates aims to prevent parents from entering the school building. In addition, teachers can immediately greet students to feel happy when they arrive at school so that they distract children from their parents. Then, students are invited to shake hands with the teachers to instill polite character.

Sometimes, grade A children still whine and don't want to be left by their parents. If something like this happens, the teacher will advise the child, hold his hand, and invite the child to chat about things that interest him for a while. At the same time, other teachers will ask parents to leave the child when the child's attention has been distracted. Thus, this activity also requires collaboration between teachers to achieve the program goals to be completed. In addition, teacher discipline is another supporting factor because teachers must arrive before 07.30 WIB to wait and welcome the arrival of their students.

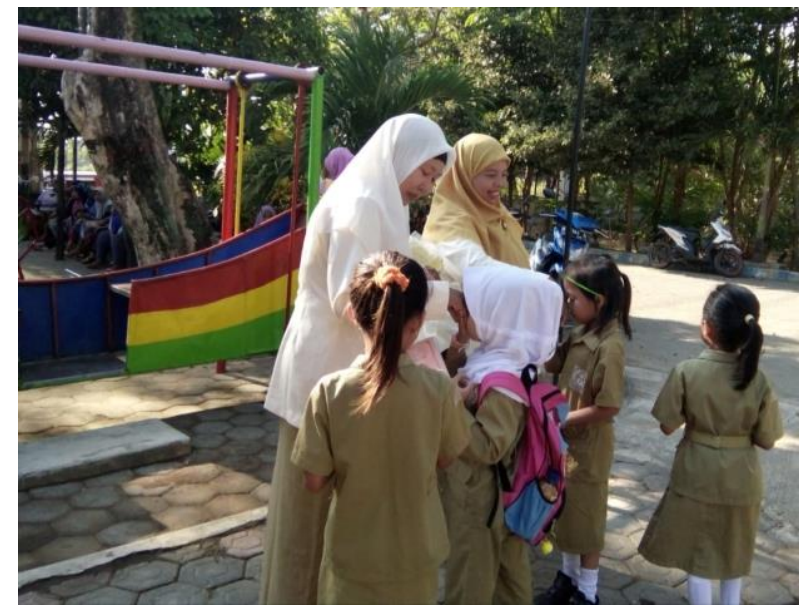

Picture 3 The teacher waits and welcomes students' arrival in front of the school gate.

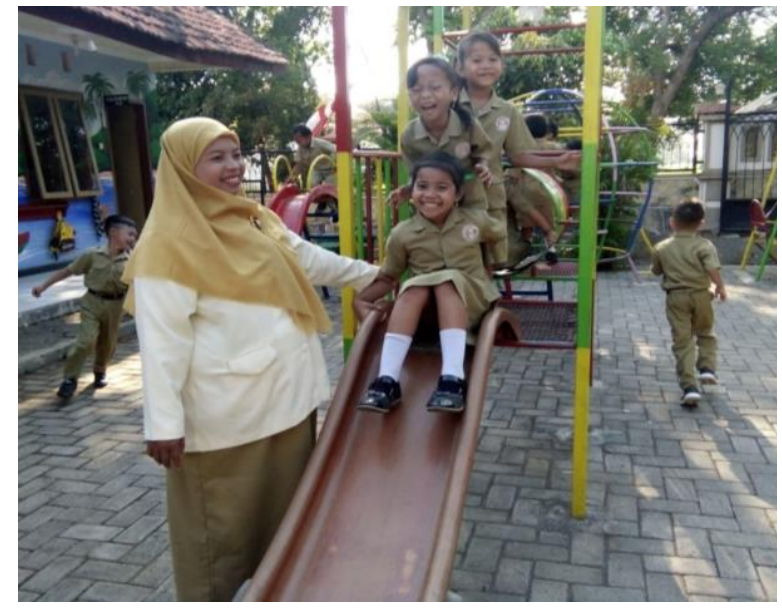

Figure 4 The teacher accompanies the students to play.

In Figure 3 above, you can see the activities of the teacher who is waiting for his students to come and teach him to shake hands. As previously explained, this activity aims to welcome children to feel happy, and children's attention to parents is diverted. However, some parents still insist on accompanying their children into the school building. To prevent this from happening, the Sinar Harapan Kindergarten teacher will urge parents who are still in the school environment to leave the school immediately and lock the school gates.

Many factors cause children always to want to be accompanied by their parents, including at school. For example, the trauma experienced by the child or the parents themselves and the lack of confidence in the new environment can even cause fear in children (Shofiyah \& Purnama, 2020). This fear is also called "protective emotion," or that children will ask for protection from their parents or adults around them (Imawati, 2019). Therefore, teachers need to persuade, seduce, and distract children from wanting to study in class without the company of their parents. In this context, teachers are required to be able to build emotional closeness with students and be creative in raising children's enthusiasm to study with friends and teachers in class (Adawiyah, 2020).

Second, the teacher accompanies the children playing during recess. The primary purpose of holding this activity is to help students get to know their friends. When the teacher joins the playground, it will be easier to interact with his students. In addition, playtime can be an excellent time to start a friendship. This condition is a perfect opportunity to train children to be confident when blending in with their environment. If the child is satisfied, it 
can trigger their courage to hang out with their peers. Thus, when students return to class, they can interact more intensively with their friends. The homeroom teacher of class A1 also said that when children can get along with their friends, learning that must be done in groups can also be easier to do.

The second activity included in the "Aku Bisa" program is also an effort by the teacher to keep students safe while playing. Because it is not uncommon for students to fall while playing. In addition, some students fight with other friends because they fight over the game due to their high ego attitude. One of the Sinar Harapan Kindergarten teachers(Widiastutik, 2021)also said that when several students were involved in an argument, one of the students would usually cry. This will also affect the learning process that will be carried out after the break is over because the child's psychological condition is sad, angry, or disappointed, so that he does not focus on the teacher's explanation.

In Figure 4, the activities of the teacher who was accompanying the students to play during recess can be seen. The relationship between this activity and efforts to train children's independence lies in the role of the teacher in introducing their students to each other. Thus, children will get along with friends in their new environment, so they don't always depend on other adults when dealing with other people. In addition, this activity is also one of the teacher's efforts to foster children's courage and independence in using the game correctly and adequately. Indeed, at first, the teacher must always be near students who still have difficulty getting along. However, as time goes by, the teacher will release the students slowly and only observe from a certain distance so that the child will be braver and able to play and mingle with his friends. However, occasionally the teacher will go around if students need help when they want to ride one of the rides.

A child's independence begins with the courage to face the situations faced in everyday life (Nurnaningsih \& Mansoer, 2020; Mubarak \& Humaidah, 2021). Training children to be brave by playing is also an effort to train independence in a fun way. This courage itself is triggered by self-confidence in the child's soul. In line with this, the psychoanalytic theory proposed by Sigmund Freud and Erik Erikson (in Pratiwi, 2017) states that play can help develop children's confidence when they can master the body, objects, and social skills. Another important thing that is obtained from the association with friends is that children will learn to interact and adapt to their social environment to avoid egoism and individualism (Pebriana, 2017; Firdausiah, 2021).

Third, teach children to use the toilet regularly (toilet training). This activity is carried out to control urination and defecation regularly. Usually, every half hour, the teacher will offer their students to go to the bathroom or toilet. This is because most students are still ashamed or afraid to go to the bathroom. The teacher also teaches children to wash their hands regularly related to this toilet training. Every lesson will be held after the break is over. In addition, handwashing activities are taught every time students have finished learning skills such as sticking and coloring so that students' hands are clean from skill equipment that makes hands dirty. However, Sinar Harapan Kindergarten teachers will also monitor and teach students to wash their hands every time they eat during recess. To facilitate the third activity of the "Aku Bisa" program, Sinar Harapan Kindergarten provides a sink and hand soap in front of each class. That way, access to washing hands becomes easier because children don't have to go to the bathroom to wash their hands.

Figure 5 shows the activities of students when washing their own hands in the sink located in front of the class. This activity is carried out with the teacher's supervision to wash their hands properly and do not wastewater. Toilet training and hand washing activities are an effort to train children's independence which requires close interaction between children and adults because the closeness of the exchange will create a sense of security and confidence in children to express their desire to urinate or defecate or to clean their hands (Ahmad \& Masykuroh, 2021). Toilet training trains children to express their urge to urinate or defecate and trains them to take off and put their pants back on and teach them to flush the toilet 
correctly and adequately (I. Hasanah et al., 2019). Not only that, the activity of washing their own hands can train children's initiative in doing something (Danauwiyah \& Dimyati, 2021).

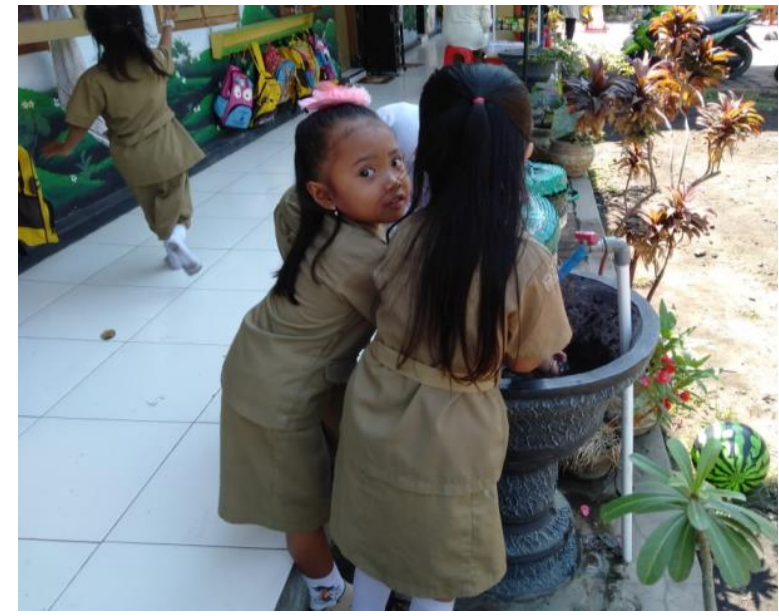

Figure 5 Children learn to wash their own hands.

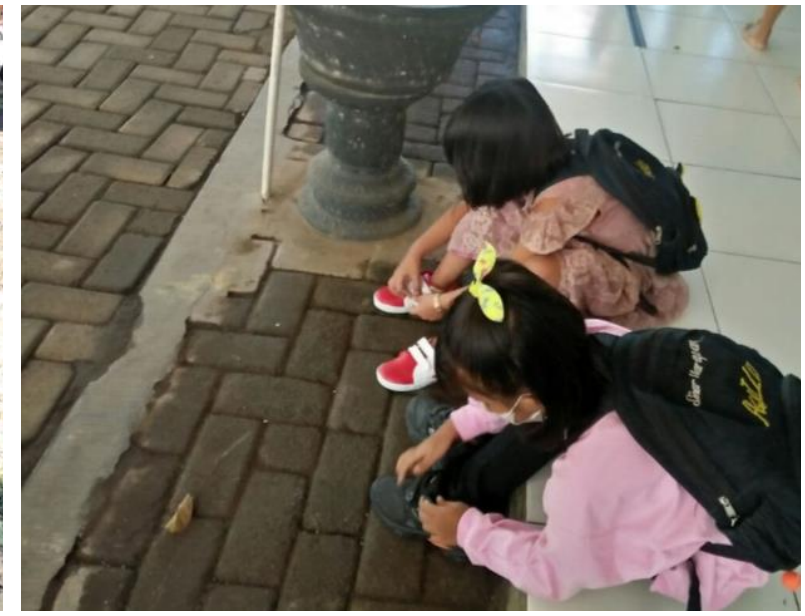

Figure 6 Students putting on their shoes

Fourth, tidy up school supplies and put on their shoes. The main objective of this activity is for children to get used to maintaining, caring for, and using their belongings properly without the help of adults. This activity also teaches children to be responsible for their belongings. The teacher will occasionally direct students who are often impatient when putting on shoes. Therefore, to support this activity, the teacher also urges students' parents to provide shoes without laces so that children do not have trouble putting on their shoes.

In Figure 6, it can be seen that students are putting on their shoes when learning at school is over. Tidying up school supplies and putting on one's shoes are included in practical life activities to train the spirit of independence through daily lifeactivities (Khotijah, 2018). In this context, the emphasis on useful life is life at school. In addition, the actions of tidying up school supplies and putting on their shoes are an effort to train children's independence in taking care of themselves and meeting their daily needs (Wijayanti et al., 2019). That way, children are accustomed to relying on their abilities in every activity.

In addition to implementing the four main activities mentioned above, the "Aku Bisa" program also involves parents to support the program's success. This is done by evaluating the parent meeting held every two months. In this meeting, the teacher will inform the development of students' independence and continue to urge parents not always to obey and serve children in various activities. Through this evaluation activity, the Sinar Harapan Kindergarten teacher council seeks to instill the importance of parental awareness and support in training children's independence from an early age. Because the support of parents who are family or parties who are always close to the child can help optimize the child's independence (O. A. Sari et al., 2017).

The "Aku Bisa" program applied in TK Sinar Harapan is emphasized on children in class A who have just entered the school world. The emphasis on efforts to train independence in previous research (Simatupang et al., 2021) also focused on children in class A. The emphasis is based on the fact that children who are just entering the school world will also enter a different new environment where children must also learn to have new skills in order to adapt properly. Because, children will face new challenges when entering the wider social world (Vernita et al., 2018). The difference between this study and previous studies lies in the activities of the "I Can" program which combines the practice of independence with simple habituation accompanied by teacher efforts to establish closeness with children so that children are more confident. In previous researches (Atalia et al., 2021; Rukmandari et al., 2020), teachers trained children's independence by doing fun learning such as through circle 
time and show and tell so that children are confident as provisions to be independent. While in previous research (Simatupang et al., 2021), teachers trained children's independence by doing some habituation such as taking their own peci, tidying stationeries up, and marching neatly in front of the class. However, the "Aku Bisa" program combines the two so that the child grows into a confident person as well as independent at the same time.

\section{CONCLUSION}

One of the efforts to train children's independence is to do small but routine things such as through a good habituation. The "Aku Bisa" program is a planned activity designed by the Sinar Harapan Kindergarten teacher council to train children's independence and overcome various problems caused by children's independence. In this case, the emphasis of the "Aku Bisa" program is focused on grade A students who have just entered the school environment. The "Aku Bisa" program consists of a series of simple activities carried out regularly so that children become accustomed to it. Independent learning does not appear to be forced or authoritarian but relatively gradual. From this program, training children's independence requires the support and cooperation of various parties, including parents, so that they do not always serve their children's wishes.

\section{ACKNOWLEDGMENT}

The researcher would like to thank the Chancellor of the University of Nurul Jadid, Paiton, Probolinggo, East Java, and the entire board of teachers of Sinar Harapan Kindergarten, Jrebeng Wetan sub-district, Kedopok sub-district, Probolinggo city who have provided motivation and support for this completion study. Hopefully, this research can provide benefits and inspiration for future researchersin developing learning innovations in schools.

\section{REFERENCES}

Adawiyah, R. (2020). Geografi Emosi Orang Tua Dalam Menghadapi Hari Pertama Sekolah Anak Usia Dini Di Masa New Normal. Ejurnal La Tansa Mashiro.

Affrida, E. N. (2017). Strategi Ibu dengan Peran Ganda dalam Membentuk Kemandirian Anak Usia Pra Sekolah. Jurnal Obsesi: Jurnal Pendidikan Anak Usia Dini, 1(2), 114. https://doi.org/10.31004/obsesi.v1i2.24

Ahmad, Z., \& Masykuroh. (2021). Strategi Kepala Sekolah dalam Menerapkan Program Perilaku Hidup Bersih dan Sehat (PHBS) pada Anak Usia Dini. Jurnal Pendidikan Anak, 10(1), 59-68. https:// doi.org/10.36722/jaudhi.v3i1.588

Alfina, A., \& Anwar, R. N. (2020). Manajemen Sekolah Ramah Anak Paud Inklusi. Al-Tanzim: Jurnal Manajemen Pendidikan Islam, 4(1), 36-47. https://doi.org/10.33650/altanzim.v4i1.975

Ali, M., \& Lukmanulhakim, L. (2019). Peran Guru Dalam Melatih Kemandirian Anak Usia 45 Tahun Di TK Negeri Pembina Meliau. Jurnal Pendidikan Dan Pembelajaran Khatulistiwa, 8(9).

Amaliyah, A., Rahman, F., \& Maryam, S. (2022). Enhancement School Competitiveness Through A Literacy Culture Based on Local Wisdom. Jurnal Obsesi: Jurnal Pendidikan Anak Usia Dini, 6(3), 2325-2333. https://doi.org/10.31004/obsesi.v6i3.2094

Anggraeni, A. D. (2017). Kompetensi Kepribadian Guru Membentuk Kemandirian Anak Usia Dini (Studi Kasus di TK Mutiara, Tapos Depok). AWLADY : Jurnal Pendidikan Anak, 3(2), 28. https:// doi.org/10.24235/awlady.v3i2.1529

Ariefin, S. (2021). Wawancara Kepala TK. In TK Sinar Harapan (p. 5).

Ariyanti, T. (2016). Pentingnya Pendidikan Anak Usia Dini Bagi Tumbuh Kembang Anak. Jurnal Dinamika Pendidikan Dasar, 8(1), 50-58. 
Atalia, Ferawati, D., \& Multahada, A. (2021). Upaya Guru Dalam Melatih Kemandirian Anak. Primearly: Jurnal Kajian Pendidikan Dasar Dan Anak Usia Dini, 4(1), 192-199.

Baharun, H. (2017). Total Moral Quality: A New Approach for Character Education in Pesantren. Ulumuna, 21(1), 57-80. https:// doi.org/10.20414/ujis.v21i1.1167

Danauwiyah, N. M., \& Dimyati, D. (2021). Kemandirian Anak Usia Dini di Masa Pandemi Covid-19. Jurnal Obsesi: Jurnal Pendidikan Anak Usia Dini, 6(2), 588-600. https://doi.org/10.31004/obsesi.v6i2.994

Daviq, C. (2019). Analisis Kemandirian Anak Usia Dini. Paud Lectura, 3(2), 1-9. https://doi.org/10.31849/paud-lectura.v3i01.3351

Elytasari, S. (2017). Esensi Metode Montessori dalam Pembelajaran Anak Usia Dini. Jurnal Arraniry, 3(1), 59-73.

Farida, N. (2014). Metode Penelitian Kualitatif dalam Penelitian Pendidikan Bahasa. In 信阳师 范学院 (Vol. 1, Issue 1).

Finori, F. D. (2019). Smart Techno Parenting : Alternatif Pendidikan Anak pada Era Tekhnologi Digital. Jurnal Tatsqif, 17(1), 52-69. https:// doi.org/10.20414/itq.v17i1.625

Firdausiah. (2021). Implementation of Overcoming Introverted Children. 13(2).

Garnika, E., \& Suarti, N. K. A. (2018). Pengaruh Dukungan Orang Tua Terhadap Kemandirian Anak Usia Dini di PAUD Permata Bangsa. Jurnal Realita, 3(5), 5-24.

Gulo, W. (2002). Metodologi Penelitian. In Gramedia Widiasarana Indonesia (p. 262). Gramedia Widiasarana Indonesia.

Hasanah, I., Putri, E. I. E., \& Bahari, J. I. (2019). Pengaruh Toilet Training Terhadap Kemandirian Anak Usia 3-4 Tahun di KB Kartika Kepundungan Srono Banyuwangi Tahun Pelajaran 2018-2019. Ar-Risalah: Media Kesilaman, Pendidikan Dan Hukum Islam, XVII(2). https:/ / doi.org/10.29062/arrisalah.v17i2.279

Hasanah, U. (2018). Strategi Pembelajaran Aktif Untuk Anak Usia Dini. INSANIA : Jurnal Pemikiran Alternatif Kependidikan, 23(2), 204-222. https://doi.org/10.24090/insania.v23i2.2291

Hecht, M. F., \& Garber, C. E. (2021). Effectiveness of the POWER Program in Improving Physical Activity and Executive Function in Fifth Grade Students. Journal of School Health, 91(7), 574-583. https:// doi.org/10.1111/josh.13035

Iltiqoiyah, L. (2020). Manajemen Pembelajaran melalui Pendekatan BCCT dalam Meningkatkan Multiple intelligences Anak. Jurnal Obsesi : Jurnal Pendidikan Anak Usia Dini, 5(2), 1368-1381. https:// doi.org/10.31004/obsesi.v5i2.781

Imawati, D. (2019). Pengaruh Storytelling Terhadap Kemandirian Anak Prasekolah. Motiva : Jurnal Psikologi, 2(1), 37-42. https://doi.org/10.31293/mv.v1i1.3500

Indak, Y. B., \& Pratiwi, W. (2021). Peran Guru dalam Mengembangkan Kemandirian Anak Usia Dini di TK Kemala Bhayangkari 06 Gorontalo. ECIE Journal: Jurnal Pendidikan Islam Anak Usia Dini, 2(2), 63-78.

Jennah, M. (2019). Smart Parenting dalam Mengatasi Social Withdrawal pada Anak di Pondok Pesantren. Ta'allum: Jurnal Pendidikan Islam, 7(1), 45-72. https://doi.org/10.21274/taalum.2019.7.1.45-72

Khaironi, M. (2018). Perkembangan Anak Usia Dini. Jurnal Golden Age, 2(1), 1. https://doi.org/10.29408/goldenage.v2i01.739

Khotijah, I. (2018). Peningkatan Kemandirian Anak Melalui Pembelajaran Practical Life. Jurnal Golden Age Hamzanwadi Unoversity, 2(2), 127-140. https://doi.org/10.29408/goldenage.v2i02.1100

Krobo, A. (2021). Kemandirian Anak Mengurus Diri Sendiri Dikembangkan Melalui Metode Pembiasaan. PERNIK: Jurnal Pendidikan Anak Usia Dini, 4(2), 70-77.

Kusumawati, I., \& Zuchdi, D. (2019). Pendidikan Moral Anak Usia Dini Melalui Pendekatan Konstruktivis. Academy of Education Journal, 10(1), 63-75. https://doi.org/10.47200/aoej.v10i01.272 
Mahmudah. (2018). Konstruksi Pendidikan Karakter di Madrasah Berbasis Pesantren. Jurnal Mudarrisuna, 8(1), 153.

Maryam, S. (2018). Building Character Education Using Three Matra of Hasan Al-Banna'S Perspective in Pesantren. Jurnal Pendidikan Islam, 4(2), 51-62. https://doi.org/10.15575/jpi.v4i2.2422

Miles, M. B., Huberman, A. M., \& Saldana, J. (2013). Qualitative Data Analysis: A Methods Sourcebook, 3/E (third). SAGE Publications.

Muali, C., Rofiki, M., \& Sholeh, L. (2021). The Role of Sufistic-Based Kiai Leadership in Developing the Character of Santri in the Pesantren. AL-ISHLAH: Jurnal Pendidikan, 13(3), 1705-1714. https:// doi.org/10.35445/alishlah.v13i3.1012

Mufarochah, S. (2020). Pentingnya Pendidikan Moral Pada Anak Usia Dini Dimasa Pandemi. AT-THUFULY: Jurnal Pendidikan ..., 1(1), 80-89.

Mundiri, A., Baharun, H., \& Hamimah, S. (2022). Early Childhood Behavior Management Strategy based on Fun Learning Environment. Jurnal Obsesi: Jurnal Pendidikan Anak Usia Dini, 6(4), 2583-2595. https:/ / doi.org/10.31004/obsesi.v6i4.2063

Nasution, R. A. (2017). Penanamana Disiplin dan Kemandirian Anak Usia Dini dalam Metode Maria Montessori. Jurnal Raudhah, 5(2), 11.

Nuraeni. (2016). Pendidikan Karakter Pada Anak Usia Dini. Jurnal Paedogy, 3(1), 65-73.

Nuranisa, L., Triani, M., Hidayah, W. A., Aurelia, P. M., Sanusi, D. A., Nasyatul K, N., \& Khomaeny, E. F. F. (2018). Puzzle Sebagai Media Bermain Untuk Melatih Kemandirian Anak Usia Dini. Early Childhood: Jurnal Pendidikan, 2(2a), 57-65. https:// doi.org/10.35568/earlychildhood.v2i2a.286

Nurnaningsih, S., \& Mansoer, Z. (2020). Upaya Meningkatkan Kemampuan Berbahasa Pada Anak Melalui Metode Bermain Peran. Prosiding Seminar Nasional Pendidikan STKIP Kusuma Negara, 1(3), 260-273.

Pebriana, P. H. (2017). Analisis Penggunaan Gadget terhadap Kemampuan Interaksi Sosial pada Anak Usia Dini. Jurnal Obsesi : Jurnal Pendidikan Anak Usia Dini, 1(1), 1. https:// doi.org/10.31004/obsesi.v1i1.26

Pratiwi, W. (2017). Konsep Bermain Pada Anak Usia Dini. TADBIR :Jurnal Manajemen Pendidikan Islam, 5(2), 106-117.

Rozi, F., \& Lana, I. F. (2021). Implementasi Pembelajaran Jarak Jauh (PPJ) dalam Meningkatkan $\begin{array}{llll}\text { Kemandirian } \quad \text { Belajar Siswa. } & \text { Fondatia, } & 5(1), & 109-124 .\end{array}$ https:// doi.org/10.36088/fondatia.v5i1.1108

Rozi, F., Mubarak, A. F., \& Humaidah. (2021). Penggunaan Media Permainan Bola Angka Terhadap Kemampuan Mengenalkan Konsep Bilangan 1-10 pada Anak. 10(2), 266-277.

Rozi, F., Ramdlani, M., Najah, F., Azizah, N., Niswa, H., Abdillah, M., \& Rozi, F. (2021). Distance Learning and Independent Learning of Students in Higher Education. Journal of Physics: Conference Series, 1899(1). https://doi.org/10.1088/17426596/1899/1/012177

Rukmandari, O. D., Sumardi, \& Mulyadi, S. (2020). Upaya Melatih Kemandirian Pada Anak Berdasarkan Orang Tua yang Bekerja. Jurnal Ceria (Cerdas Energik Responsif Inovatif Adaptif), 3(5), 457-467.

Sari, D. R., \& Rasyidah, A. Z. (2020). Peran Orang Tua Pada Kemandirian Anak Usia Dini. $\begin{array}{llll}\text { Early Childhood: Jurnal } & \text { Pendidikan, }\end{array}$ https:// doi.org/10.35568/earlychildhood.v3i1.441

Sari, O. A., Santy, W. H., \& Kebidanan, F. (2017). Hubungan Dukungan Keluarga dengan Tingkat Kemandirian Personal Hygiene Anak Tunagrahita di SLB Tunas Mulya Kelurahan Sememi Kecamatan Benowo. Jurnal Ilmiah Kesehatan, 10(2), 164-171. https:// doi.org/10.33086/jhs.v10i2.126

Shofiyah, H., \& Purnama, S. (2020). Kemitraan Guru dan Orang Tua dalam Menangani Anak yang Masih Ditunggu pada Jam Belajar. Journal for Education Research, 1(1), 18-27. https://doi.org/10.37985/joe.v1i1.16 
Silranti, M. (2019). Pengembangan Kemandirian Anak Usia 5-6 Tahun di TK Dharmawanita Tunas Harapan. Jurnal PG-PAUD Trunojoyo : Jurnal Pendidikan Dan Pembelajaran Anak Usia Dini, 6(2), 77-83. https://doi.org/10.21107/pgpaudtrunojoyo.v6i2.5539

Simatupang, N. D., Widayati, S., Adhe, K. R., \& Shobah, A. N. (2021). Penanaman Kemandirian Pada Anak Usia Dini Di Sekolah. Jurnal Anak Usia Dini Holistik Integratif (AUDHI), 3(2), 52. https://doi.org/10.36722/jaudhi.v3i2.593

Sitanggang, R. R., \& Nuriyanti, N. (2019). Melatih Kemandirian Anak Melalui Rutinitas SehariHari. Publikasi Pendidikan, 9(2), 141. https:// doi.org/10.26858/publikan.v9i2.9015

Sriwahyuni, E., Asvio, N., \& Nofialdi, N. (2017). Metode Pembelajaran Yang Digunakan Paud (Pendidikan Anak Usia Dini) Permata Bunda. ThufuLA: Jurnal Inovasi Pendidikan Guru Raudhatul Athfal, 4(1), 44. https://doi.org/10.21043/thufula.v4i1.2010

Sufiati, V., \& Afifah, S. N. (2019). Peran perencanaan pembelajaran untuk performance mengajar guru pendidikan anak usia dini. Jurnal Pendidikan Anak, 8(1), 48-53. https://doi.org/10.21831/jpa.v8i1.26609

Suhandi A, \& Lestari T. (2021). Pengaruh Kebudayaan Menyontek Terhadap Perkembangan Kemandirian Anakupaya Pemberantasan Kebiasaanmenyontekdi Lingkungan Sekolah. Academy of Education Journal, 12, 1-9. https://doi.org/10.47200/aoej.v12i2.743

Sukatin, Karmila, P., Marini, Hidayah, R. N., Nursavitri, R., \& Pratiwi, S. V. (2019). Mendidik Kemandirian Anak Usia Dini. Jurnal Arraniry, VI(2), 172-184.

Tanu, I. K. (2019). Pentingnya Pendidikan Anak Usia Dini Agar Dapat Tumbuh Dan Berkembang Sebagai Generasi Bangsa Harapan Di Masa Depan. Adi Widya: Jurnal Pendidikan Dasar, 2(2), 19-29. https://doi.org/10.25078/aw.v2i2.960

Umami, V. (2021). Wawancara Wali Kelas A2. In TK Sinar Harapan (p. 3).

Umiarso, \& Hidayati, N. (2022). Improving Children â€TM s Cognitive Intelligence Through Literacy Management. Jurnal Obsesi: Jurnal Pendidikan Anak Usia Dini, 6(3), 15881598. https:// doi.org/10.31004/obsesi.v6i3.1817

Urfiani. (2021a). Bentuk Sikap Tidak Mandiri. In Catatan Guru (p. 2).

Urfiani. (2021b). Wawancara Wali Kelas A1. In TK Sinar Harapan (p. 2).

Vernita, L., Haenilah, E. Y., \& Anggraini, G. F. (2018). Pengaruh Bonding Orangtua Terhadap Kemandirian Anak Usia 5-6 Tahun. Indonesian Journal of Early Childhood Issues, 1(1), 103-105.

Wahid, A. H., Qodriyah, K., \& Wahyuni, S. (2022). Building a Literacy Culture Based on Local Wisdom through Women â€TM s Leadership. Jurnal Obsesi: Jurnal Pendidikan Anak Usia Dini, 6(4), 2533-2543. https:/ / doi.org/10.31004/obsesi.v6i4.2044

Widiastutik, R. (2021). Wawancara Guru. In TK Sinar Harapan (p. 6).

Wijayanti, T., Syamsuddin, M. M., \& Pudyaningtyas, A. R. (2019). Upaya Meningkatkan Kemandirian Anak Melalui Practical Life Activity Pada Anak Usia 5-6 Tahun. Jurnal Kumara Cendekia, 7(4), 440-450. https:// doi.org/10.20961/kc.v7i4.31774

Zamroni, Amir, \& Saleha, L. (2021). Pengelolaan APE Berbahan Limbah untuk Meningkatkan Kecerdasan Kognitif Anak. Jurnal Obsesi: Jurnal Pendidikan Anak Usia Dini, 5(2), 1382-1395. https:// doi.org/10.31004/obsesi.v5i2.763

Zulfaizah. (2018). Revitalisasi Pendidikan Agama dalam Pembentukan Karakter Peserta Didik di Madrasah. Elementary, 6(1), 43-62. 